\title{
Ophthalmic parameters in adult Shih Tzu dogs
}

\author{
Parâmetros oftálmicos em cães adultos da raça Shih Tzu
}

\author{
Karina Kamachi Kobashigawa ${ }^{\mathrm{I}}$ Tiago Barbalho Lima ${ }^{\mathrm{I}}$ Ivan Ricardo Martinez Padua ${ }^{\mathrm{I}}$ \\ Alexandre Augusto Franchi de Barros Sobrinho ${ }^{I}$ Fabio de Andrade Marinho \\ Kethye Priscila Ortêncio ${ }^{I}$ José Luiz Laus ${ }^{I^{*}}$
}

\begin{abstract}
Ocular surface diseases are often diagnosed in brachycephalic dogs. The ophthalmic parameters of the Shih Tzu dogs are evaluated in this study since this breed is among the most commonly affected by these diseases. In this study, ophthalmic parameters of this breed were partly studied under physical restraint. Schirmer tear test, breakup time test, aesthesiometry, biomicroscopy, non-contact specular microscopy, laser flaremetry, applanation tonometry, ultrasonography and ophthalmoscopy were carried in 48 eyes of 24 male and female dogs, aged from two to four years, weighing between 5 and $10 \mathrm{~kg}$. All dogs were from a breeding kennel. Descriptive statistics were applied to the data. Mean and standard error for Schirmer tear test was $26.145 \pm 0.803 \mathrm{~mm} \mathrm{~min}^{-1}$; breakup time test, $13.668 \pm 0.538 \mathrm{~s}$; and aesthesiometry, $2.395 \pm 0.071 \mathrm{~cm}$. The biomicroscopy evaluation showed that $70.83 \%$ of the eyes had medial entropion; $42 \%$ caruncular trichiasis; $33 \%$ distichiasis, $27 \%$ mild paracentral corneal opacity; and 13\% corneal melanosis. Mean and standard error for endothelial cell density was 2221.591 \pm 20.161 cells $\mathrm{mm}^{-2}$; endothelial cell hexagonality, $63.770 \pm 1.805 \%$; endothelial cell area, 451.895 $\pm 4.179 \mathrm{~mm}^{2}$; central corneal thickness, $0.490 \pm 0.007$

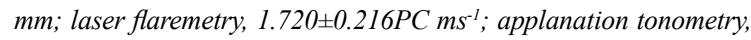
$16.118 \pm 0.460 \mathrm{mmHg}$; axial length, 20.255 $\pm 0.134 \mathrm{~mm}$; lens thickness, $6.624 \pm 0.031 \mathrm{~mm}$; anterior chamber, $4.064 \pm 0.109 \mathrm{~mm}$; and vitreous chamber, $9.565 \pm 0.054 \mathrm{~mm}$. Ophthalmoscopy findings were not different from previous reports for other breeds. The results showed that the ophthalmic Shih Tzu parameters did not differ from other breeds according to data in the literature, except for the breakup time and Cochet-Bonnet aesthesiometry.
\end{abstract}

Key words: $d o g$, Shih Tzu, ophthalmic parameters.

\section{RESUMO}

Afecções da superficie ocular são frequentes em cães braquicefálicos. Dentre as raças comumente acometidas, tem-se

\begin{abstract}
a Shih Tzu, cujos parâmetros oftálmicos não são conhecidos em sua plenitude e o foram, em parte, avaliados nesta pesquisa. Sob contenção física, empregou-se o teste lacrimal de Schirmer, o de ruptura do filme lacrimal, a estesiometria, a biomicroscopia, a microscopia especular de não contato, a flaremetria a laser, a tonometria de aplanação, a ecografia e a oftalmoscopia. Foram estudados 48 olhos de 24 individuos machos ou fêmeas, com idades variando entre dois a quatro anos e peso entre cinco a $10 \mathrm{~kg}$. Aos dados, aplicou-se a estatística descritiva. Relativamente às médias e aos erros padrão, encontraram-se, quanto ao teste

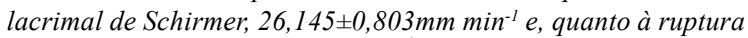
do filme lacrimal, 13,668 $\pm 0,538$ s. À estesiometria, encontraram-

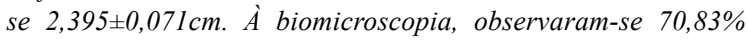
dos olhos com entrópio de canto medial, 42\% apresentaram pelos em carúncula medial, 33\% distiquíase, 27\% opacidade paracentral e 13\% melanose corneal. Médias e erros padrão, no que concerne à densidade de células endoteliais, foram de $2221,591 \pm 20,161$ céls $\mathrm{mm}^{-2}$. Quanto à hexagonalidade, foram de $63,770 \pm 1,805 \%$; quanto à área, foram de 451,895 $44,179 \mathrm{~mm}^{2}$;

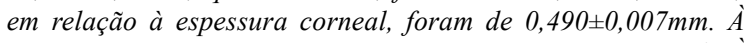
flaremetria a "laser", encontraram-se 1,720 $\pm 0,216 P C \mathrm{~ms}^{-1}$. A tonometria, 16,118 $00,460 \mathrm{mmHg}$. As médias e os erros padrão, à ultrassonografia, foram de 20,255 $\pm 0,134 \mathrm{~mm}$ para diâmetro axial horizontal; de 6,624 $\pm 0,031 \mathrm{~mm}$, para espessura da lente; de 4,064 $\pm 0,109 \mathrm{~mm}$, para profundidade da câmara anterior; e de $9,565 \pm 0,054 \mathrm{~mm}$, para a câmara vitrea. O padrão de imagens à oftalmoscopia não divergiu do já reportado em cães de outras raças. De consoante com os resultados obtidos, há como admitir que parâmetros de referência para cães adultos da raça Shih Tzu, estudados na presente pesquisa, não divergiram sobremaneira dos conhecidos para outras raças de cães, à exceção do tempo de ruptura do filme lacrimal, cujos valores ficaram aquém da média para a espécie, e os da estesiometria de Cochet-Bonnet, que foram superiores.
\end{abstract}

Palavras-chave: cão, Shih Tzu, parâmetros oftálmicos.

'Departamento de Clínica e Cirurgia Veterinária, Faculdade de Ciências Agrárias e Veterinárias, Universidade Estadual Paulista (UNESP), Via de Acesso Prof. Paulo Donato Castellane s/n, 14884-900, Jaboticabal, SP, Brasil. E-mail: jllaus@fcav.unesp.br. "Corresponding author. 


\section{INTRODUCTION}

Ophthalmic disorders are common in dogs (GILGER, 2007), especially in brachycephalic breeds, due to the anatomical configuration of the skull with increased exposure of the eyeball (brachycephalic syndrome). Diseases such as exophthalmos, lagophthalmos, medial corner entropion, nasal trichiasis, distichiasis, changes in tear production and keratopathy by exposure are cited. According to the "Universities Federation for Animal Welfare" (2011), the Shih Tzu breed is one of the most severely affected.

Early diagnosis of eye diseases is necessary to adopt quick and effective treatment, but assertive diagnoses are only feasible when the reference values for each breed are known. Therefore, the ophthalmic parameters of Shih Tzu dogs are assessed in this study since the vision system of this breed is not fully known for dogs born in Brazil.

\section{MATERIAL AND METHODS}

It was studied 48 eyes of 24 Shih Tzu dogs (Canis familiares), of which, 10 males. The dogs were between two and four years old and weighed between 5 and $10 \mathrm{~kg}$. The animals were all from the "Tutti Piccolli" kennel in Jaboticabal, SP, Brazil, and belonged to four different lineages of the breed. The dogs were selected for the study after assessing their history and general medical conditions by performing a physical examination, total blood count, evaluation of hepatic, renal functions and blood glucose.

The Schirmer tear test (STT) (Schirmer test - Ophthalmos, São Paulo, Brazil), breakup time test (BUTT) (Fluoresceina strips - Ophtalmos, São Paulo, Brazil) and Cochet-Bonnet aesthesiometry (C-B) (Cochet-Bonnet aesthesiometer, Luneau Ophthalmologie, Paris), starting with 4-cm stimulus length, were conducted under physical restraint. The upper and lower eyelids and the nictitating membrane were evaluated microscopically (Portable slit-lamp SL-14, Kowa). The bulbar and palpebral conjunctivas, cornea, anterior chamber, iris and lens were evaluated, as well. Images from the central area of the cornea were obtained by non-contact specular microscopy (Specular Microscopy SP- 3000P, Topcon, Japan) and used to determine density (cells $/ \mathrm{mm}^{2}$ ) (DE), hexagonality (\%) (HE), corneal endothelial cell area $\left(\mu \mathrm{m}^{2}\right)(\mathrm{EA})$, and central thickness (mm) (CT). A minimum of 50 cells were evaluated and the values were transferred to "Cell Count" software (Cell count, Topcon, Japan).
Laser flaremetry (LF) (Laser Flare Meter FM- $600^{\circledR}$, Kowa, Japan) and applanation tonometry (IOP) (Tono-Pen Vet - Veterinary Tonometer, Reichert) were also determined. Local anesthesia consisted of $0.5 \%$ proparacaine hydrochloride (Anestalcon, Alcon $^{\circledR}$, São Paulo, SP). Ultrasonography (Ultra-son Ultrascan A/B - Alcon ${ }^{\circledR}$ ) was carried out by resorting to manual restraint and using contact gel (Supra Gel, Adlin Plasticos LTDA, Jaraguá do Sul, SC) via the transcorneal method. The A and B modes were applied simultaneously, using a $20 \mathrm{MHz}$ probe, to evaluate eye horizontal axial length (AL), lens thickness (L), as well as the anterior (AC) and vitreous (VC) chamber lengths. The posterior segment was determined using images obtained by ophthalmoscopy (Retinal Camera TCR-50DX, Topcon) performed after pupillary dilation with $1 \%$ tropicamide (Tropinom, Genom Oftalmologia ${ }^{\circledR}$, Ebu-Guaçu, SP).

Statistical normality (MedCalc Software, Broekstraat 52, B-9030 Mariakerke, Belgium) of the continuous variables was tested using the Kolmogorov-Smirnov test at 5\% significance level and $95 \%$ confidence interval. The data were expressed as mean, standard deviation and median.

\section{RESULTS AND DISCUSSION}

Table 1 shows the mean, median and standard error values for the parameters STT, BUTT, C-B, specular microscopy (DE, HE, EA and CT), LF, IOP and ultrasonography (AL, L, AC and VC).

STT values were above the lower threshold described for the species, which is $15 \mathrm{~mm}$ $\mathrm{min}^{-1}$ (WEICHSLER, 2008). However, the results were similar to the values reported by OLLIVIER et al. (2007), and higher than those submitted by LIMA et al. (2011). According to ANDRADE (2008), STT is influenced by environmental factors, age, sex, breed, altitude, climate, circadian variation and pharmaceuticals, among others (BERGER; KING, 1998; OLLIVIER et al., 2007; ANDRADE, 2008).

Mean BUTT was lower than the value reported by OLLIVIER et al. (2007). There are reports in the literature of mean values of $20 \pm 5 \mathrm{~s}$ (ANDRADE, 2008). LIMA et al. (2011) found significantly lower density of goblet cells in the conjunctiva of Shih Tzu dogs compared to those described by other authors. The low quantity of mucin-producing cells can influence how long it takes for the tear film to adhere to the epithelium of the cornea (ISREB et al., 2003). BUTT values did not follow the Gaussian distribution, although they displayed symmetry. The abnormal 
Table 1 - The mean, median and standard error values for the Schirmer tear test (STT- millimeters per minute); breakup time test (BUTT seconds); Cochet-Bonnet aesthesiometry (C-B - milimeters); specular microscopy, cell density (DE - cells per square millimeter), hexagonality (HE - percentage); endothelial cell area (CA - square micrometers) and corneal thickness (CT - millimeters); laser flaremetry (LF - photons per millisecond); intraocular pressure (IOP - millimeters of mercury); and the ultrasound, on the axial length of the eyeball (AL - mm), lens thickness (LT - millimeters), the length of the anterior (AC - millimeters) and vitreous (VC millimeters) chambers measured in 24 eyes of adult Shih Tzu dogs from a kennel in Jaboticabal, SP, 2013.

\begin{tabular}{lcc}
\hline & Mean \pm standard error & Median \\
\hline STT $(\mathrm{mm} / \mathrm{min})^{*}$ & $26.145 \pm 0.803$ & 27.500 \\
BUTT $(\mathrm{s})$ & $13.668 \pm 0.538$ & 13.000 \\
C-B $(\mathrm{cm})$ & $2.395 \pm 0.071$ & 2.500 \\
DE $\left(\mathrm{cells} / \mathrm{mm}^{2}\right)^{*}$ & $2221.591 \pm 20.161$ & 2214.050 \\
HE $(\%)^{*}$ & $63.770 \pm 1.805$ & 64.000 \\
CA $\left(\mathrm{mm}^{2}\right)^{*}$ & $451.895 \pm 4.179$ & 451.650 \\
CT $(\mathrm{mm})^{*}$ & $0.490 \pm 0.007$ & 0.493 \\
LF $(\mathrm{PC} / \mathrm{ms})^{*}$ & $1.720 \pm 0.216$ & 15.300 \\
IOP $(\mathrm{mmHg})^{*}$ & $16.118 \pm 0.460$ & 15.300 \\
AL $(\mathrm{mm})^{*}$ & $20.255 \pm 0.134$ & 20.190 \\
LT $(\mathrm{mm})^{*}$ & $6.624 \pm 0.031$ & 6.590 \\
AC $(\mathrm{mm})^{*}$ & $4.064 \pm 0.109$ & 4.090 \\
VC $(\mathrm{mm})^{*}$ & $9.565 \pm 0.054$ & 9.510 \\
\hline
\end{tabular}

*Gaussian distribution of the Kolmogorov-Smirnov test $(\mathrm{p}<0.05)$.

distribution could be attributed to the occurrence of outliers $(8.33 \%$ of the data).

KAFARNIK et al. (2008) reported that the density of nerve fibers in the subepithelial corneal nerve plexus is smaller in brachycephalic dogs. The corneal sensitivity found in this study was higher than that described for beagles by LISBÃO et al. (2012). The Cochet-Bonnet test results may, however, be considered subjective when used for such purposes, since the palpebral reflex may be inconsistent (OLLIVIER et al., 2007; RIBEIRO, 2010).

The slit-lamp biomicroscopy results showed that $70.83 \%$ of the eyes had medial corner entropion; $42 \%$ exhibited hair in the medial caruncle; $33 \%$ had distichiasis; $27 \%$ had mild paracentral corneal macula; and 13\%, corneal melanosis. The occurrence of medial corner entropion, hair in caruncle, distichiasis, macula and melanosis corroborates the data published by the "Universities Federation for Animal Welfare" (2011) for the Shih Tzu breed and brachycephalic ocular syndrome.

The mean endothelial cell density did not differ from that found by NAGATSUYU et al. (2014) for dogs of different breeds. The cell area was greater than that described by RODRIGUES et al. (2006), and similar to that found by NAGATSUYU et al. (2014). Hexagonality percent values were higher than those reported by NAGATSUYU et al. (2014), but similar to those found by PIGATTO et al. (2008). The differences between the means found in the present study and those found by ROBERTS et al. (2006) are assumed to be due to the differences between the methods used and the breeds studied. Figure 1 shows the specular microscopy image.

The central corneal thickness did not differ from that reported by SAMUELSON (2007). The mean value of $0.490 \pm 0.007 \mathrm{~mm}$ obtained in the present study is similar to those reported by GILGER et al. (1991) and GALLEGO et al. (2012) for several breeds. The laser flaremetry results are similar to those found by YOGO et al. (2002) and KHRONE et al. (1995) for different breeds, as well. The mean intraocular pressure values were within the standard range for the species (BROOKS, 2008; MARTINS et al., 2009; PARK et al., 2011). The IOP values may vary as a result of aging, changes in blood pressure, action of drugs, circadian variations and ocular inflammation (MARTINS et al., 2009).

Ultrasonography showed that the horizontal axial diameter is similar to that described by SAMUELSON (2007) and TONI et al. (2013) in brachycephalic dogs. The values were not significantly different from those found by MARTINS et al. (2010) in dogs of various breeds. The central thickness of the lens was similar to the values reported by TONI et al. (2013) for brachycephalic dogs, and by MATTOON \& NYLAND (2002) and SAMUELSON (2007) for dogs of different breeds. The depth values of the anterior chamber were similar to those presented by TONI et al. (2013) while the mean values of the 


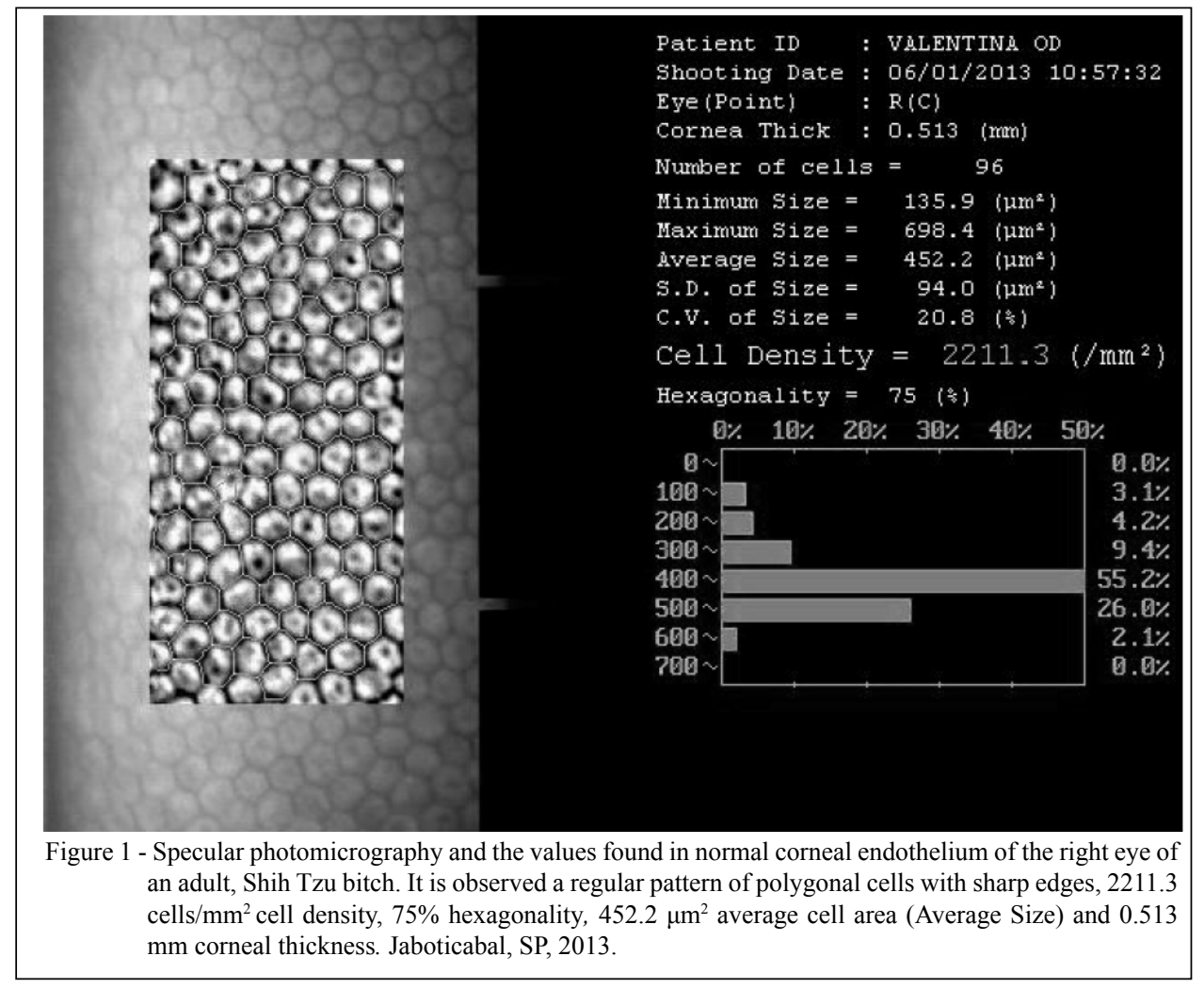

vitreous chamber were also similar. All obtained images were similar to known parameters for dogs (Figure 2).

Ultrasound reference values are of great importance when determining conformation changes (BAPTIST et al., 2006), deciding the size of ocular prostheses to be used (TONI et al., 2013), and choosing intraocular lenses, relatively to its measures, in cataract surgery (GAIDDON et al., 1991; SAMPAIO et al., 2002). Moreover, for monitoring the evolution of diseases, such as glaucoma and after chemical ablation of the ciliary body (BRANDÃO et al., 2007).

None of the dogs showed any visible change to ophthalmoscopy, and the findings are not different from the normal pattern described for dogs (Figure 3). The optic disc was predominantly located in the non-tapetal area ( $62.5 \%$ of eyes).

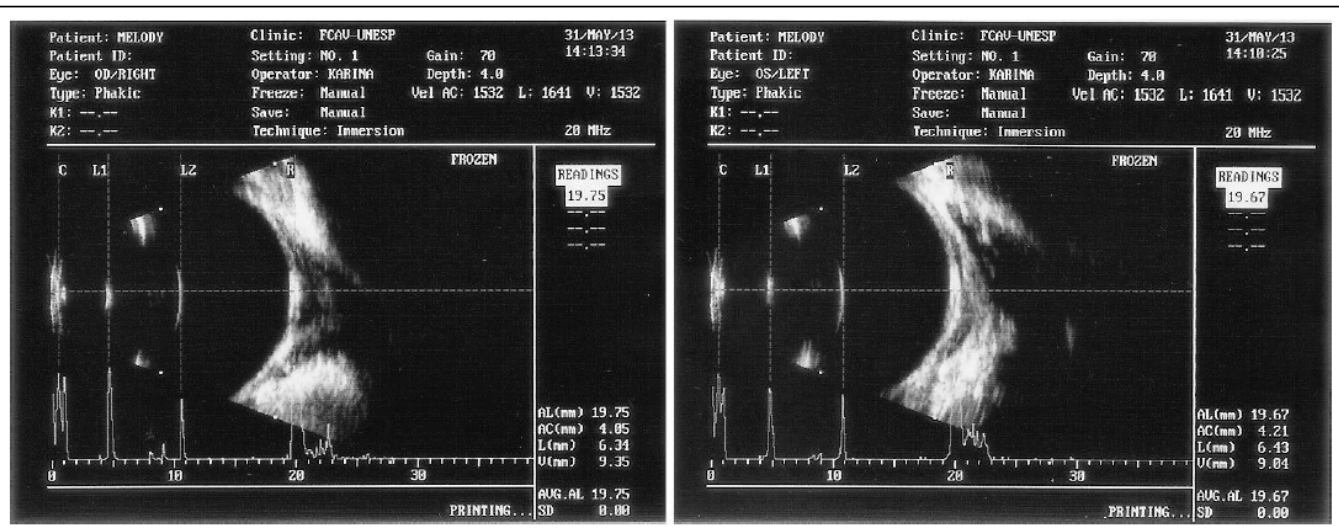

Figure 2 - Ultrasound images in A and B modes showing the biometrics of the right and left eyeball, respectively, of an adult Shih Tzu bitch. The patterns observed are compatible with those described for the canine species. Axial length of the eyeball (AL), anterior chamber length (AC), lens thickness (LT), vitreous chamber length (VC), C: cornea (C), lens anterior (L1) and posterior (L2) capsules and retina (R). Jaboticabal, SP, 2013. 


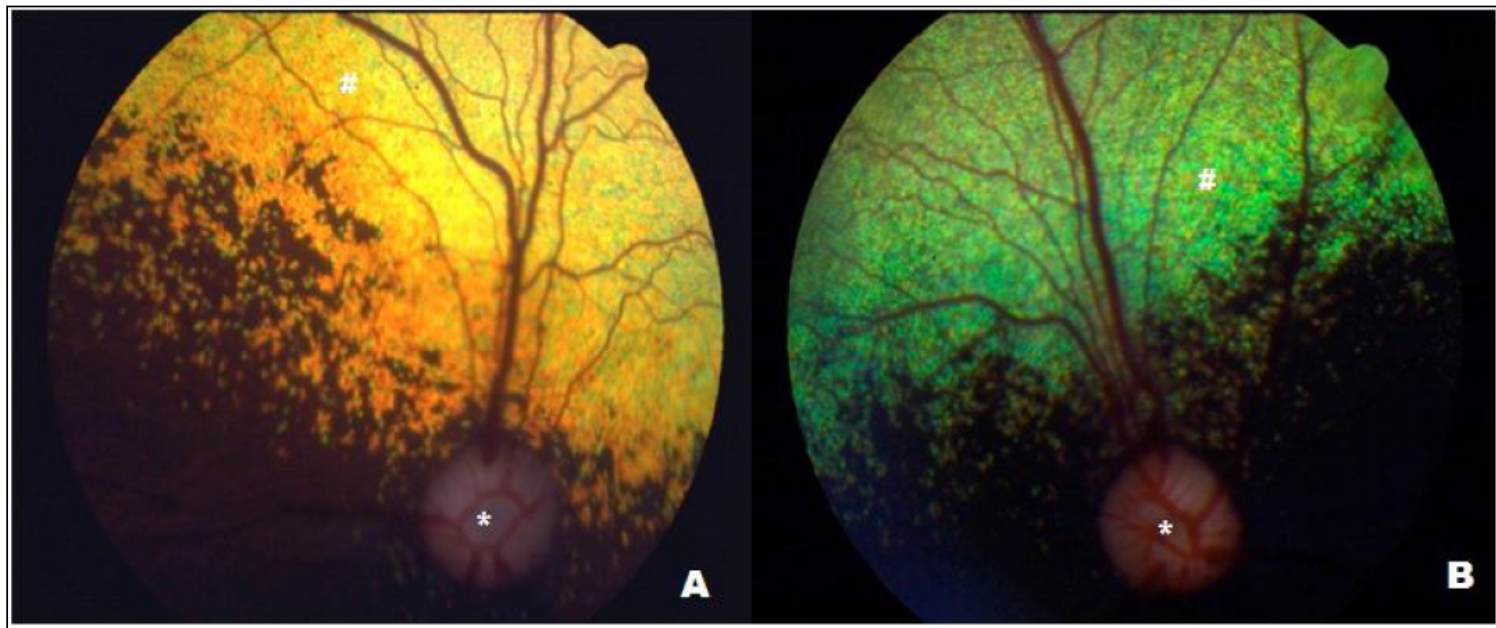

Figure 3 - Images showing the normal fundus of the eyes of adult Shih Tzu dogs. Image A shows the left eye of a male dog. Image B shows the right eye of a bitch. Note the staining of the tapetal area (\#) and the round optical disk located in non-tapetal (*) area. Jaboticabal, SP, 2013

The studied sample population was homogeneous, from the same kennel and from a small age bracket. The possibility of inbreeding should not be considered since the kennel maintains four different lineages and all four were studied in this research.

\section{CONCLUSION}

Ophthalmic parameters found for Brazilian adult Shih Tzu dogs were not different from those reported for other breeds, except for the breakup time of the tear film and the Cochet-Bonnet aesthesiometry values, which were below and above the average for the species, respectively. The knowledge of the reference values for each breed assists greatly when diagnosing and treating ophthalmic diseases.

\section{ACKNOWLEDGEMENTS}

To the Coordenação de Aperfeiçoamento de Pessoal de Nivel Superior (CAPES), for the scholarship, and to the Conselho Nacional de Desenvolvimento Científico e Tecnológico (CNPq), process number 300833/2010-5.

\section{ETHICS COMMITTEE}

The project was approved by the Ethics Committee on Animal Use (CEUA), College of Agricultural and Veterinary Sciences, Universidade Estadual Paulista (UNESP), in Jaboticabal (Protocol 001 686/11 of 22/03/2011).

\section{REFERENCES}

ANDRADE, A.L. Semiologia do sistema visual dos animais domésticos. In: FEITOSA, F.L.P. Semiologia veterinária. São Paulo: Roca, 2008. Cap.14, p.623-653.
BAPTISTA, C.S. et al. Standardised B-scan and A-scan echographic evaluation of the spontaneous anterior uveal melanomas in the dog. Veterinary Journal, v.171, p.322-330, 2006. Available from: <http://www.sciencedirect.com/science/ article/pii/S1090023304002473>. Accessed: Mar. 23, 2013.

BERGER, S.L.; KING, V.L. The fluctuation of tear production on the dog. Journal of American Hospital Association, v.34, n.1, p.79-83, 1998. Available from: <http://www.ncbi.nlm.nih.gov/ pubmed/9527434>. Accessed: Sept. 12, 2013.

BERNASCONI, O. et al. Sensiitivity of laser flare photometry compared to slit-lamp cell evaluation in monitoring anterior chamber inflammation in uveitis. International Ophthalmology, v.30, p.495-500, 2010. Available from: <http://www.ncbi.nlm.nih. gov/pubmed/20686916>. Accessed: Sept. 12, 2013. doi: 10.1007/ s10792-010-9386-8.

BRANDÃO, C.V.S. et al. Tonometria, paquimetria e comprimento axial ocular em cães glaucomatosos submetidos à ablação uveal intravítrea. Arquivo Brasileiro de Medicina Veterinária e Zootecnia, v.59, p.914-919, 2007. Available from: $<$ http://www.scielo.br/scielo.php?script=sci_arttext\&pid $=$ S0102-09352007000400016 $>$. Accessed: Sept. 20, 2013. doi: 10.1590/S0102-09352007000400016.

BROOKS, D.E. Glaucoma. In: HERRERA, D. Oftalmologia clínica em animais de companhia. São Paulo: Medvet, 2008. p.195-203.

GAIDDON, J. et al. Use of biometry and keratometry for determining optimal power for intraocular-lens implants in dogs. American Journal of Veterinary Research, v.52, p.781-783, 1991. Available from: <http://apps.webofknowledge.com/full record.do?product $=\mathrm{UA} \&$ search_mode $=$ GeneralSearch\&qid $=3 \&$ $\mathrm{SID}=3 \mathrm{C} 7 \mathrm{e} 2 \mathrm{rKPkFbbVyGeE} 8 \mathrm{p} \& \mathrm{page}=3 \& \mathrm{doc}=22>$. Accessed: Sept. 14, 2013.

GALEGO, M.P. etal. Estudo comparativo das estruturas do segmento anterior de olhos de cães normais e com catarata, portadores ou não de Diabetes mellitus, avaliados por biomicroscopia ultrassônica. 
Pesquisa Veterinária Brasileira, v.32, n.1, p.66-71, 2012. Available from: <http://www.scielo.br/scielo.php?pid=S0100736X2012000100011\&script $=$ sci_arttext $>$. Acessed: Apr. 10, 2012. doi: 10.1590/S0100-736X2012000100011.

GILGER, B.C. et al. Canine corneal thickness measured by ultrasonic pachymetry. American Journal of Veterinary Research, v.52, p.1570-1572, 1991. Available from: <http://www ncbi.nlm.nih.gov/pubmed/1767973>. Accessed: Apr. 10, 2012.

GILGER, B.C. Diseases and surgery of the canine corneal and sclera. In: GELLAT, K.N. Veterinary ophthalmology. 4.ed. Iowa: Blackwell Publishing, 2007. V.2, p.690-745.

ISREB, M.A. et al. Correlation of lipid layer thickness measurements with fluorescein tear film break-up time and Schirmer's test. Eye, n.17, p.79-83, 2003. Available from: $<$ http://www.ncbi.nlm.nih.gov/pubmed/12579175>. Accessed: Jul. 04, 2013.

KAFARNIK, C. et al. Corneal innervations in mesocephalic and brachycephalic dogs and cats: assessment using in vivo confocal microscopy. Veterinary Ophthalmology, v.11, n.6, p.363-367, 2008. Available from: <http://www.ncbi.nlm. nih.gov/pubmed/19046276>. Accessed: Sept. 10, 2013. doi: 10.1111/j.1463-5224.2008.00659.x.

KROHNE, S.G. et al. Use of laser flaremetry to measure aqueoushumor protein-concentration in dogs. Journal of American Veterinary Medical Association, v.206, p.1167-1172, 1995 Available from: $<$ http://www.ncbi.nlm.nih.gov/pubmed/7768737>. Accessed: May 18, 2012.

LIMA, A.M.V. et al. Produção lacrimal e densidade de células caliciformes conjuntivais em cães da raça Shih Tzu. Ciência Animal Brasileira, v.12, n.2, p.353-358, 2011. Available from: <http:// www.revistas.ufg.br/index.php/vet/rt/printerFriendly/8049/9263>. Accessed: Sept. 10, 2013. doi: 10.5216/cab.v12i2.8049.

LISBÃO, C.B.S. et al. Effects of the Ottonia martiana Miq. (Piperaceae) extract on dog's ocular surface. Arquivo Brasileiro de Medicina Veterinária e Zootecnia, v.64, n.3, 2012. Available from: <http://www.scielo.br/scielo.php?script $=$ sci arttext\&pid $=\mathrm{S} 0102-09352012000300008 \& \operatorname{lng}=\mathrm{en} \& \mathrm{nrm}=\mathrm{is}$ o\&tlng=en>. Accessed: Jun. 27, 2012. doi: 10.1590/S010209352012000300008 .

MARTINS, B.C. et al. A and B mode ultrasonography in preoperative evaluation of lens and posterior segment of dogs' eyes with cataract. Pesquisa Veterinária Brasileira, v.30, p.121126, 2010. Available from: <http://dx.doi.org/10.1590/S0100736X2010000200004>. Acessed: Ago. 25, 2013. doi: 10.1590/ S0100-736X2010000200004.

MARTINS, B.C. et al. Glaucoma. In: LAUS, J.L. Oftalmologia clínica e cirúrgica em cães e gatos. São Paulo: Roca, 2009. p. 151-157.

MATTOON, J.S.; NYLAND, T.G. Eye. In: Small animal diagnostic ultrasound. Philadelphia: Saunders, 2002. p.305-322.

NAGATSUYU, C.E. et al. Non-contact specular microscopy in aphakic and pseudophakic dogs. Arquivo Brasileiro de Medicina Veterinária e Zootecnia, v.44, n.4, p.682-687, 2014. Available from: <http://www.scielo.br/scielo.php?pid=S0103- 84782014000400018\&script $=$ sci_arttext $>$. Accessed: Jun. 27, 2012. doi: $10.1590 / \mathrm{S} 0103-84782014000400018$.

OLLIVIER, F.J. et al. The eye examination and diagnostic procedures. In: GELLAT, K.N. Veterinary Ophthalmology. 4.ed. Iowa: Blackwell Publishing, 2007. p.438-476.

PARK, Y. et al. Effect of central corneal thickness on intraocular pressure with the rebound tonometer and the applanation tonometer in normal dogs. Veterinary Ophthalmology, v.14, n.3, p.169-173, 2011. Available from: <http://www.ncbi.nlm.nih.gov/ pubmed/21521440>. Accessed: Mar, 21, 2012. doi: 10.1111/j.14635224.2010.00859.x

PIGATTO, J.A.T. et al. Morphological analysis of the corneal endothelium in eyes of dogs using specular microscopy. Pesquisa Veterinária Brasileira, v.28, n.9, p.427-430, 2008. Available from: $<$ http://www.scielo.br/scielo.php?pid=S0100736X2008000900006\&script $=$ sci_abstract $>$. Accessed: Sept. 27, 2013. doi: 10.1590/S0100-736X2008000900006.

RIBEIRO, A.P. Duração do efeito analgésico e expressão de diferentes metaloproteinases, do colágeno tipo IV e da interleucina-10, em córneas de coelhos tratadas com morfina, após ceratectomia lamelar. 2010. 75f. Tese (Doutorado em Cirurgia Veterinária) - Faculdade de Ciência Agrárias e Veterinárias, Universidade Estadual Paulista "Júlio de Mesquita Filho", Jaboticabal, SP.

RODRIGUES, G.N. et al. Corneal endothelial cell morphology of normal dogs in different ages. Veterinary Ophthalmology, v.9, n.2, p.101-107, 2006. Available from: <http://www.ncbi.nlm.nih. gov/pubmed/16497234>. Accessed: Jun. 06, 2013.

SAMUELSON, D.A. Ophthalmic anatomy. In: GELLAT, K.N. Veterinary ophthalmology. 4.ed. Iowa: Blackwell Publishing, 2007. V.1, p.49-87.

SAMPAIO, G.R. et al. Sexo, peso e conformação anatômica do olho sobre o cálculo de poder dióptrico de lentes intra-oculares no cão. Ciência Rural, v.32, n,2, p.263-268,, 2002. Available from: $<$ http://dx.doi.org/10.1590/S0103-84782002000200013>. Acessed: set. 10, 2013. doi: 10.1590/S0103-84782002000200013.

TONI, M.C. et al. Ophthalmic ultrasound of dogs with different skull conformations. Agrária - Revista Brasileira de Ciências Agrárias, v.8, n.2, p.331-335, 2013. Available from: <http://www. agraria.pro.br/sistema/index.p?journal=agraria\&page=article\&op $=$ viewArticle $\&$ path $\% 5 \mathrm{~B} \% 5 \mathrm{D}=$ agraria v8i2a2396>. Acessed: out. 30, 2013. doi: 10.5039/agrária.v8i2a2396.

UNIVERSITIES FEDERATION FOR ANIMAL WELFARE. Geneticwelfareproblems of companionanimals-Brachycephalic ocular syndrome, 2011 [on line]. Available from: $<$ http://www. ufaw.org.uk/BRACHYCEPHALICOCULARSHIHTZU.php>. Accessed: Set. 12, 2013.

WEICHSLER, N Exame do olho e anexos. In: HERRERA, D. Oftalmologia clínica em animais de companhia. São Paulo: MedVet, 2008, Cap.2, p.31-48.

YOGO, T. et al. Evaluation on canine and feline aqueous flare using a laser flare meter. Animal Eye Research, v. 21, n. 1/2, p. 23-27, 2002. 